\title{
Municipal Engineer: Referees 2016
}

The following is a list of referees who have reviewed papers for Municipal Engineer between 1 December 2015 and

30 November 2016. The Institution of Civil Engineers is very grateful for their assistance.

We are continually looking for suitable reviewers for papers submitted to Municipal Engineer. Papers published in the Proceedings of the ICE must be submitted to at least two independent referees to judge accuracy, style, impact, importance and interest.
A. Almeida
S. Amin
R. Andrew
B. Bach
S. Balouch
J. Bateman
D. Bayliss
J. Ben-Edigbe
T. Bennett
S. Bowers
C. Boyko
R. Brown
S. Burgess
M. Castro
A. Chanan
B. Clarke

D. Collings

J. Coutinho-Rodrigues

L. Cunningham

J. Curiel-Esparza

J. Deller

O. Demir

C. Evans

H. Evdorides

A. Faggi

N. Ferguson

J. Foster-Clark

A. Gibbs

A.P. Gomes

C. Greed

N. Gupta

B. Hakim
If you are interested in reviewing articles on any topic related to engineering history and heritage, please submit your name, qualifications or $\mathrm{CV}$, and areas of expertise. We are in need of individuals who will agree to review papers in a timely fashion (within 3 to 4 weeks of receipt) and provide confidential feedback to the Editorial Advisory Panel concerning the quality of the paper and any suggested revisions that would be appropriate.

If you are such a person, please contact Claire Robinson

(tel.: +44 (0)207 665 2241; e-mail: claire.robinson@icepublishing.uk) for more information on the referee process.
P. Hallsworth
A. Hayes
R. Hughes
R. Huxford
I. Jenkinson
M. Karacasu
M. Kirk
Y.C. Kog
W. Lawn
R. Marques
N. Metje
M. Miguez
G. Newson
R. Ortega
F. Osorio
A. Rugumayo

N. Sousa

A. Stainsby

R. Sterling

W. Tayler

M. Templeton

N. Thom

J. Thomson

H. Titheridge

M. Valipour

P. Welsh

C. Whitehead

J. Ye 